\title{
BIGH3 is overexpressed in clear cell renal cell carcinoma
}

\author{
MASANORI YAMANAKA ${ }^{1}$, FUMIHIRO KIMURA ${ }^{1}$, YUTAKA KAGATA ${ }^{2}$, NOBUO KONDOH ${ }^{3}$, \\ TOMOHIKO ASANO $^{1}$, MIKIO YAMAMOTO ${ }^{3}$ and MASAMICHI HAYAKAWA ${ }^{1}$ \\ Departments of ${ }^{1}$ Urology, ${ }^{2}$ Pathology II and ${ }^{3}$ Biochemistry II, National Defense \\ Medical College, 3-2 Namiki, Tokorozawa-shi, Saitama 359-8513, Japan
}

Received September 11, 2007; Accepted October 26, 2007

\begin{abstract}
To identify new target marker genes in renal cell carcinoma (RCC), we compared the gene expression profiles of clear cell RCC (cc-RCC) and normal kidney tissue using serial analysis of gene expression. Our results revealed that the transforming growth factor $\beta$ induced $68 \mathrm{kDa}$ protein $(T G F-\beta I$ : $\beta$ ig-h3 (BIGH3), plasminogen activator inhibitor-1 (PAI-1) and transforming growth factor $\beta 1(T G F-\beta 1)$ genes are upregulated in cc-RCC. To further assess the role of $B I G H 3$ in RCC, we investigated the mRNA expression levels of $B I G H 3$, $T G F \beta 1, P A I-1$ and also of $T G F-\beta 1$ related genes in 53 RCC and 30 normal kidney tissues by quantitative real-time RT-PCR (QRT-PCR). We further determined the BIGH3 protein levels in $52 \mathrm{cc}$-RCC paraffin-embedded tissue samples by immunohistochemistry. BIGH3 mRNA was found to be highly overexpressed in cc-RCC compared with normal tissues with an average ratio of 27 . The mRNA levels of TGF- $\beta 1$ and PAI-1 were also detected at significantly elevated levels in these cancers. Immunohistochemical analysis of $\mathrm{BIGH} 3$ also revealed strong staining in the majority of the cc-RCC samples. In addition, the up-regulation of $B I G H 3$ and $P A I-1$ was found to correlate with the clinicopathological parameters associated with a poorer patient outcome, whereas $T G F-\beta 1$ expression was determined to be unrelated to cancer progression. Strong BIGH3 staining thus tended to be associated with a poor prognosis. BIGH3 was also induced in some RCC cell lines by TGF- 31 stimulation and this correlated well with PAI- 1 upregulation, suggesting that these enhancements are regulated by a similar mechanism in these tumors.
\end{abstract}

\section{Introduction}

Renal cell carcinoma (RCC) is the most common malignancy of the adult kidney, for which clear cell RCC (cc-RCC) is the

Correspondence to: Dr Fumihiro Kimura, Deptartment of Urology, National Defense Medical College, 3-2 Namiki, Tokorozawa-shi, Saitama 359-8513, Japan

E-mail: fkmr@ndmc.ac.jp

Key words: renal cell carcinoma, $\beta$ ig-h3, plasminogen activator inhibitor-1, transforming growth factor $\beta 1$, Smads, quantitative realtime reverse transcription PCR most common subtype and accounts for 75 to $80 \%$ of all cases (1). The prognosis for RCC is based on tumor stage and histopathological grade (2) and the survival of the affected patients with metastases remains quite poor, in spite of the available adjuvant immunotherapies involving interferon and/or interleukin-2 administration (1). In contrast, localized RCC can be successfully treated by radical surgery, though $\sim 30 \%$ of such patients with apparently non-metastatic disease at the time of diagnosis suffer from subsequent metastases and usually die from cancer recurrence (3).

Although the tumor stage and grade provide quite reliable prognostic information in cases of RCC, the behaviour of these cancers is often unpredictable. New prognostic markers are therefore desirable for a better prediction of patient outcomes and are likely to provide novel insights into the pathophysiology of this disease. In an attempt to identify new biomarkers of RCC, we analyzed and compared the gene expression profiles of a cc-RCC primary tumor (pT4, M1) and normal adjacent renal cortex tissue using serial analysis of gene expression (SAGE).

From our SAGE experiments, 70 genes were found to be up-regulated by more than 3-fold in RCC compared with normal kidney tissue. Among these genes, three transforming growth factor $\beta(T G F-\beta)$ related genes: plasminogen activator inhibitor-1 (PAI-1), TGF- $\beta$-induced $68 \mathrm{kDa}$ protein $(T G F-\beta I)$ and $T G F-\beta 1$ were found to be up-regulated by $21-, 12-$ and 7-fold, respectively, in RCC compared with normal kidney tissue. $T G F-\beta I$ is referred to as ' $\beta$ ig- $h 3$ ' (BIGH3) hereafter to avoid confusion with TGF- $\beta 1$. In general, TGF- $\beta$ binds to the TGF- $\beta$ receptor and then signals one or more downstream effectors, of which the Smads are the best characterized (4).

TGF- $\beta 1$ is a potent inhibitor of normal epithelial cell growth, however, its role in human malignancies is complex, as evidence shows by both its positive and negative influences on cancer development at several levels (4). In RCC, TGF- 11 is overexpressed and this is associated with cancer progression (5). In contrast, the TGF- $\beta$ type II receptor (TGF-ßRII) is down-regulated with cancer progression $(6,7)$. Cancer cell escape from the growth suppressive effects of TGF- 11 can thus be partly explained by this down-regulation of TGF- 3 RII. The roles of the Smads, which are intermediates of TGF- $B$ signalling, have not been well examined in RCC. In general, however, SMAD4 acts as an agonist, whereas SMAD7 acts as an antagonist, of TGF- $ß$ signalling $(4,8)$.

$B I G H 3$ encodes a small polypeptide that was initially isolated from the A549 lung adenocarcinoma cell line as an 
up-regulated gene following TGF- $\beta 1$ treatment $(9,10)$. Missense mutations in the BIGH3 gene destabilize this protein resulting in the formation of 'amyloidogenic intermediates' that are deposited in the cornea and cause a hereditary corneal dystrophy (11). Most of the studies of $\mathrm{BIGH} 3$ have focused on this disease. BIGH3 harbours an RGD sequence that can serve as a ligand recognition site for several integrins and that also influences both cell attachment and migration $(10,12)$. This suggests its involvement in cellular adhesion and a possibly significant role in tumor progression.

The ectopic expression of BIGH3 in asbestos-induced tumorigenic cells inhibits cell growth in vitro, and the tumorigenicity of these cells in nude mice (13). The transfection of $\mathrm{BIGH} 3$ into $\mathrm{CHO}$ fibroblasts was also found to reduce the ability of these cells to form tumors in nude mice (10). These findings further suggest a possible tumor suppressor role for BIGH3.

Recently, the overexpression of BIGH3 has been shown in both RCC tissues (14-16) by the result of gene array analysis and in other tumors including lung cancer (17), oesophageal cancer (18), pancreatic carcinoma (19) and colon cancer (20). BIGH3 mRNA expression in RCC has not been well characterised, however, and we therefore analysed the $B I G H 3$ and TGF- $\beta 1$ pathway-related mRNA levels ( $T G F-\beta R I I$, SMAD4, SMAD7, PAI-1) in cc-RCC tissues in our current study by quantitative real-time reverse transcription PCR (QRT-PCR). PAI-1 is an additional down-stream target of TGF- $\beta 1$. Our findings were examined in the context of the available clinicopathological information for the corresponding patients, and were further complemented by immunohistochemical investigations using a polyclonal anti-BIGH3 antibody. In addition, we surveyed the levels of BIGH3 expression and its inducibility by TGF- $\$ 1$ in several RCC cell lines.

\section{Materials and methods}

Patients. Cc-RCC and adjacent kidney tissue samples were collected from 53 patients, who had undergone a nephrectomy. All samples were immediately snap-frozen in liquid nitrogen and stored at $-80^{\circ} \mathrm{C}$ until use. All of the patients had confirmed RCC of the clear cell type and were treated at the National Defense Medical College (NDMC) Hospital from 2000 to 2003. The NDMC Ethics Committee approved this study and each patient gave prior informed consent. Clinicopathological factors were determined after surgery according to the 1997 TNM system (21) and the General Rules for Clinical and Pathological Studies on Renal Cell Carcinoma of the Japanese Urological Association, 3rd Edition, 1999 (22). Clinicopathological data for patients with renal tumors studied in the mRNA analysis are listed in Table I. For immunohistochemical analysis, we used 52 paraffinembedded tissue samples. The patients consisted of 38 men and 14 women. The mean patient age was $60.4 \pm 11.0$ years (range 39-78). The histological grade contained only G1 and G2 elements in 37 and G3 elements in 15 samples. The T stage (based on the TNM staging system) was T1 in 29, T2 in 5, T3 in 17 and T4 in 1. The clinical stage was Stage I in 26, Stage II in 4, Stage III in 7 and Stage IV in 15.
Cell lines. The human RCC cell lines ACHN and A498 were purchased from the American Type Culture Collection (ATCC) (Manassas, VA, USA). The RCC cell lines SKRC44 and SKRC49 were obtained from the Memorial Sloan Kettering Institute (New York, NY, USA). All RCC lines were maintained in Dulbecco's modified Eagle's medium (DMEM) supplemented with $2 \mathrm{mM}$ glutamine, $1 \%$ nonessential amino acids, $100 \mathrm{U} / \mathrm{ml}$ streptomycin and penicillin and $10 \%$ foetal calf serum (FCS). Human renal proximal tubular epithelial cells (RPTEC) were purchased from ATCC and grown in Renal Epithelial Cell Basal Medium (REBM, Clonetics, San Diego, CA) supplemented with REGM complex $(0.5 \mu \mathrm{l} / \mathrm{ml}$ hydrocortisone, $10 \mathrm{pg} / \mathrm{ml} \mathrm{hEGF,} 0.5 \mu \mathrm{g} / \mathrm{ml}$ epinephrine, $6.5 \mathrm{pg} / \mathrm{ml}$ triiodothyronine, $10 \mu \mathrm{g} / \mathrm{ml}$ transferrin, $5 \mu \mathrm{g} / \mathrm{ml}$ insulin, $1 \mu \mathrm{g} / \mathrm{ml}$ gentamycin sulphate and $0.5 \%$ FCS).

Cell proliferation assay. Cell growth was assayed using the CellTiter 96 nonradioactive cell proliferation assay (Promega, USA). Briefly, RCC cell lines were plated overnight at $5 \times 10^{3}$ cells/well and RPTECs at $1 \times 10^{4}$ cells/well in 96-well plates. The following day, the media were exchanged and treated in the absence or presence of $10 \mathrm{ng} / \mathrm{ml}$ TGF- $\beta 1$ (Sigma, USA). On day three of the treatment, cell growth was determined by adding MTT solution (50 $\mu \mathrm{g} /$ well) for $4 \mathrm{~h}$. Subsequently, MTT assay products were solubilized with acidic isopropanol and the optical densities were measured at $570 \mathrm{~nm}$ with a plate reader.

TGF- $\beta 1$ treatments. The RCC cell lines A498, SKRC49 and RPTEC were exposed to $10 \mathrm{ng} / \mathrm{ml}$ TGF- $\beta 1$ for $12,24,48$ and $72 \mathrm{~h}$, followed by expression analysis of $B I G H 3$ and $P A I-1$ by QRT-PCR (see below). Maximal stimulation of these genes by TGF- $\beta 1$ was found to occur after $48 \mathrm{~h}$, as reported in a previous study (9), and the expression of these genes in untreated cells at this timepoint was thus considered to represent the basal levels. We subsequently evaluated all of the treated cell lines after $48 \mathrm{~h}$ exposure to TGF-B1. A498, SKRC44 and ACHN cells were plated overnight at $5 \times 10^{4}$ cells/

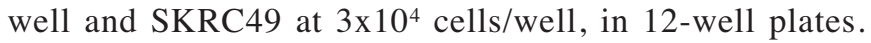
RPTECs were plated at $4 \times 10^{5}$ cells/well in 6 -well plates. The following day, the media were exchanged and the cells were further cultured in the absence or presence of $10 \mathrm{ng} / \mathrm{ml} \mathrm{TGF-} \beta 1$. After $48 \mathrm{~h}$ treatment, RNA was extracted and the PAI- 1 and $B I G H 3$ mRNA levels were evaluated, as described below.

RNA extraction and reverse transcription. Total RNA was extracted from kidney specimens using an Isogen kit (Nippon Gene, Japan) according to the manufacturer's instructions and further purified with an RNeasy Mini kit (Qiagen, Tokyo, Japan). Total RNA was extracted in the same manner from both the RCC cell lines and RPTEC cells. Reverse transcription of RNA ( $1 \mu \mathrm{g})$ was performed in a final volume of $20 \mu \mathrm{l}$ containing 5xRT buffer, 0.1 M DTT, $200 \mathrm{U}$ of SuperScriptII enzyme (Invitrogen), $10 \mathrm{mM}$ dNTP and oligo $(\mathrm{dT})_{18}$. The reaction mixture was then incubated at $42^{\circ} \mathrm{C}$ for $50 \mathrm{~min}$, and the reverse transcriptase was inactivated by heating at $70^{\circ} \mathrm{C}$ for $15 \mathrm{~min}$.

Quantitative real-time $R T$-PCR ( $Q R T-P C R)$. PCR reactions were performed in a final reaction volume of $25 \mu 1$ containing 
Table I. Clinicopathological data obtained in the RCC patients for whom mRNA analysis was performed.

\begin{tabular}{|c|c|c|c|c|c|c|c|}
\hline No. & Age & Sex & Grade $^{a}$ & Diameter $(\mathrm{cm})$ & $\mathrm{PT}^{\mathrm{b}}$ & Stage $^{b}$ & Site of metastasis ${ }^{\mathrm{b}}$ \\
\hline 1 & 58 & $\mathrm{~m}$ & $\mathrm{G} 1>\mathrm{G} 2$ & 1.7 & $1 \mathrm{a}$ & I & \\
\hline 2 & 66 & $\mathrm{~m}$ & $\mathrm{G} 1>\mathrm{G} 2$ & 2.0 & $1 \mathrm{a}$ & I & \\
\hline 3 & 62 & $\mathrm{f}$ & G2 & 2.2 & $1 \mathrm{a}$ & I & \\
\hline 4 & 43 & $\mathrm{~m}$ & $\mathrm{G} 1>\mathrm{G} 2$ & 2.3 & $1 \mathrm{a}$ & I & \\
\hline 5 & 73 & $\mathrm{f}$ & $\mathrm{G} 2$ & 2.3 & $1 \mathrm{a}$ & I & \\
\hline 6 & 72 & $\mathrm{f}$ & $\mathrm{G} 2>\mathrm{G} 1$ & 2.5 & $1 \mathrm{a}$ & I & \\
\hline 7 & 54 & $\mathrm{~m}$ & G2 & 2.5 & $1 \mathrm{a}$ & I & \\
\hline 8 & 62 & $\mathrm{~m}$ & $\mathrm{G} 2>\mathrm{G} 1$ & 2.6 & $1 \mathrm{a}$ & I & \\
\hline 9 & 72 & $\mathrm{f}$ & $\mathrm{G} 1>\mathrm{G} 2$ & 2.8 & $1 \mathrm{a}$ & I & \\
\hline 10 & 49 & $\mathrm{~m}$ & $\mathrm{G} 2>\mathrm{G} 1$ & 3.0 & $1 \mathrm{a}$ & I & \\
\hline 11 & 43 & $\mathrm{~m}$ & $\mathrm{G} 1>\mathrm{G} 2$ & 3.5 & $1 \mathrm{a}$ & I & \\
\hline 12 & 62 & $\mathrm{f}$ & G1 & 3.6 & $1 \mathrm{a}$ & I & \\
\hline 13 & 48 & $\mathrm{~m}$ & $\mathrm{G} 1>\mathrm{G} 2$ & 3.8 & $1 \mathrm{a}$ & I & \\
\hline 14 & 40 & $\mathrm{f}$ & $\mathrm{G} 1>\mathrm{G} 2$ & 4.0 & la & I & \\
\hline 15 & 39 & $\mathrm{f}$ & $\mathrm{G} 1>\mathrm{G} 2$ & 4.0 & la & I & \\
\hline 16 & 68 & $\mathrm{f}$ & $\mathrm{G} 2>\mathrm{G} 1$ & 4.0 & la & I & \\
\hline 17 & 75 & $\mathrm{~m}$ & $\mathrm{G} 2>\mathrm{G} 3$ & 4.0 & la & I & \\
\hline 18 & 71 & $\mathrm{~m}$ & $\mathrm{G} 2>>\mathrm{G} 3$ & 4.2 & $\mathrm{Ib}$ & I & \\
\hline 19 & 54 & $\mathrm{~m}$ & $\mathrm{G} 2>\mathrm{G} 1$ & 4.4 & $\mathrm{Ib}$ & I & \\
\hline 20 & 76 & $\mathrm{~m}$ & $\mathrm{G}>>\mathrm{G} 1>\mathrm{G} 3$ & 4.5 & $\mathrm{Ib}$ & I & \\
\hline 21 & 67 & f & G2 & 4.7 & $\mathrm{Ib}$ & I & \\
\hline 22 & 39 & $\mathrm{f}$ & $\mathrm{G} 1>\mathrm{G} 2$ & 5.0 & $\mathrm{Ib}$ & I & \\
\hline 23 & 79 & $\mathrm{~m}$ & $\mathrm{G} 1>\mathrm{G} 2$ & 5.0 & $\mathrm{Ib}$ & I & \\
\hline 24 & 73 & $\mathrm{~m}$ & $\mathrm{G} 2>\mathrm{G} 1$ & 5.0 & $\mathrm{Ib}$ & I & \\
\hline 25 & 44 & $\mathrm{~m}$ & $\mathrm{G} 2>\mathrm{G} 1$ & 5.0 & $\mathrm{Ib}$ & I & \\
\hline 26 & 69 & $\mathrm{~m}$ & $\mathrm{G} 2>\mathrm{G} 1$ & 5.0 & $\mathrm{Ib}$ & I & \\
\hline 27 & 60 & f & $\mathrm{G} 2>\mathrm{G} 3$ & 5.0 & $\mathrm{Ib}$ & I & \\
\hline 28 & 61 & $\mathrm{f}$ & $\mathrm{G} 1>\mathrm{G} 2$ & 5.5 & $\mathrm{Ib}$ & I & \\
\hline 29 & 57 & $\mathrm{~m}$ & $\mathrm{G} 2>\mathrm{G} 3$ & 5.5 & $\mathrm{Ib}$ & I & \\
\hline 30 & 66 & $\mathrm{~m}$ & $\mathrm{G} 2 \gg>\mathrm{G} 3$ & 5.6 & $\mathrm{Ib}$ & I & \\
\hline 31 & 46 & $\mathrm{~m}$ & $\mathrm{G} 2>\mathrm{G} 1$ & 6.8 & $\mathrm{Ib}$ & I & \\
\hline 32 & 68 & $\mathrm{~m}$ & $\mathrm{G} 2>\mathrm{G} 3$ & 6.8 & $\mathrm{Ib}$ & I & \\
\hline 33 & 77 & f & $\mathrm{G} 3=\mathrm{G} 2$ & 7.0 & 2 & II & \\
\hline 34 & 53 & $\mathrm{~m}$ & $\mathrm{G} 2>\mathrm{G} 3$ & 7.1 & 2 & II & \\
\hline 35 & 61 & $\mathrm{f}$ & $\mathrm{G} 2>\mathrm{G} 1$ & 7.5 & 2 & II & \\
\hline 36 & 51 & $\mathrm{f}$ & $\mathrm{G} 2 \gg \mathrm{G} 3$ & 8.5 & 2 & II & \\
\hline 37 & 49 & $\mathrm{~m}$ & $\mathrm{G} 2 \gg \mathrm{G} 3$ & 9.3 & 2 & II & \\
\hline 38 & 51 & $\mathrm{~m}$ & $\mathrm{G} 2>\mathrm{G} 1$ & 11 & 2 & II & \\
\hline 39 & 66 & $\mathrm{~m}$ & G2 & 4.8 & $3 a$ & III & \\
\hline 40 & 76 & $\mathrm{~m}$ & $\mathrm{G} 2>\mathrm{G} 1$ & 7.4 & $3 a$ & III & \\
\hline 41 & 77 & $\mathrm{~m}$ & $\mathrm{G} 2>\mathrm{G} 3$ & 8.9 & $3 a$ & III & \\
\hline 42 & 72 & $\mathrm{f}$ & $\mathrm{G} 2>\mathrm{G} 3$ & 9.8 & $3 \mathrm{a}$ & III & \\
\hline 43 & 73 & $\mathrm{f}$ & $\mathrm{G} 2>\mathrm{G} 3$ & 11 & $3 a$ & III & LN (N1) \\
\hline 44 & 81 & $\mathrm{~m}$ & $\mathrm{G} 2>\mathrm{G} 1$ & 6.5 & $3 b$ & III & \\
\hline 45 & 71 & $\mathrm{~m}$ & $\mathrm{G} 3>\mathrm{G} 2$ & 4.0 & la & IV & Lung \\
\hline 46 & 70 & $\mathrm{~m}$ & $\mathrm{G} 2>>\mathrm{G} 1$ & 5.4 & $\mathrm{Ib}$ & IV & Lung, LN, bone \\
\hline 47 & 57 & $\mathrm{~m}$ & $\mathrm{G} 2>>\mathrm{G} 3$ & 6.5 & $\mathrm{Ib}$ & IV & Bone, chest wall, adrenal gl. \\
\hline 48 & 55 & $\mathrm{~m}$ & $\mathrm{G} 2>\mathrm{G} 1$ & 9.2 & 2 & IV & Lung, brain, spinal cord \\
\hline 49 & 65 & $\mathrm{~m}$ & $\mathrm{G} 1>\mathrm{G} 2$ & 7.0 & $3 \mathrm{a}$ & IV & Lung, bladder \\
\hline 50 & 69 & $\mathrm{~m}$ & $\mathrm{G} 2>\mathrm{G} 3$ & 7.0 & $3 \mathrm{a}$ & IV & Bone (Th3) \\
\hline 51 & 70 & $\mathrm{~m}$ & $\mathrm{G} 3>\mathrm{G} 2$ & 8.0 & $3 a$ & IV & Lung \\
\hline 52 & 42 & $\mathrm{~m}$ & $\mathrm{G} 2>\mathrm{G} 1>>\mathrm{G} 3$ & 10 & $3 b$ & IV & Lung \\
\hline 53 & 61 & $\mathrm{~m}$ & $\mathrm{G} 3>>\mathrm{G} 2$ & 18 & 4 & IV & LN (N2), lung, liver invasion \\
\hline
\end{tabular}

aTumor grade was determined according to the General Rules for Clinical and Pathological Studies on Renal Cell Carcinoma of the Japanese Urological Association, 3rd Edition, 1999. ${ }^{\text {b}}$ Tumor stage was determined after surgery, according to the 1997 TNM system. The site of metastasis at surgery is also described. 
Applied Biosystems' Assay-on-Demand 2xUniversal Master Mix and 20xTarget and endogenous control Assay Mix (containing each primer and the Taq Man MGB probe). Products were detected using the GeneAmp 5700 Taq Man PCR detector system (PE Applied Biosystems). The following Target assay mixers (PE Applied Biosystems) were used: Hs00165908-ml for BIGH3, Hs00171257-ml for $T G F-\beta 1$, Hs00559661-ml for TGFßRII, Hs00232068-ml for SMAD4, Hs00178696-ml for SMAD7, Hs00167155-ml for PAI-1 and endogenous control Assay Mix: Hs99999903 for Actin- $\beta$ $(A C T \beta)$.

Diluted cDNA templates were used for quantitative PCR $\left(10 \mathrm{~min}\right.$ at $95^{\circ} \mathrm{C}$, followed by 40 cycles of $15 \mathrm{sec}$ at $95^{\circ} \mathrm{C}$ and $1 \mathrm{~min}$ at $60^{\circ} \mathrm{C}$ ). Each sample was analyzed in duplicate. A standard curve was constructed using 10-fold serial dilutions of cDNA obtained from the A498 RCC cell line. For each experimental sample, the amount of the targets and the endogenous reference (ACTB) were determined from the standard curve. The target amounts were then divided by the endogenous reference amount to obtain a normalized target value. ACTB was selected as the endogenous reference gene as its expression between RCC and kidney tissue was found to be nearly equivalent in our SAGE analysis.

Polyclonal antibody production and purification. The BIGH3 protein sequence was obtained from UniProt and a synthetic peptide corresponding to human $\mathrm{BIGH}_{3542-554}$ (PTNEAFRAL PPRE) was synthesized. An antibody was raised against this peptide in rabbits by KOHJIN-BIO (Sakado, Saitama, Japan) using the following immunization schedule: an initial injection of $0.3 \mathrm{mg}$ followed by 4 injections of $0.3 \mathrm{mg}$ every 2 weeks. For affinity purification of the raised antibody, the same peptide was immobilized on a Sulfolink coupling gel (Pierce). Antiserum was passed over the column, which was then washed with PBS ( $\sim 5$ column volumes). Bound antibody was eluted with $100 \mathrm{mM}$ glycine ( $\mathrm{pH}$ 2.7), immediately neutralized with $1 \mathrm{M}$ Tris base ( $\mathrm{pH} 9.0$ ) and adjusted to a concentration of $1.0 \mathrm{mg} / \mathrm{ml}$ before storage at $-20^{\circ} \mathrm{C}$.

Immunohistochemistry. For immunohistochemical analysis, formalin-fixed, paraffin-embedded tissue sections $4 \mu \mathrm{m}$ in thickness were deparaffinised in xylene, rehydrated in a graded ethanol series and autoclaved for $15 \mathrm{~min}$ with $10 \mathrm{mmol} / \mathrm{l}$ sodium citrate buffer ( $\mathrm{pH}$ 6.0) prior to staining. The endogenous peroxidase activity was inactivated by incubation in $3 \% \mathrm{H}_{2} \mathrm{O}_{2}$ for $10 \mathrm{~min}$. Tissue sections were then incubated with polyclonal anti-rabbit BIGH3 antibody (1:50 dilution,

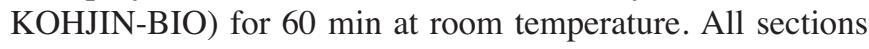
were sequentially treated using the Envision+ method (Dako Cytomation, Glostrup, Denmark) for $60 \mathrm{~min}$ and then with 3,3'-diaminobenzidine in the presence of hydrogen peroxidase. The sections were then lightly counterstained with hematoxylin. As a negative control, the anti-BIGH3 antibody was replaced with non-immune rabbit serum.

BIGH3 antigen expression was assessed in tumor samples (containing normal tissue components) from $52 \mathrm{cc}-\mathrm{RCC}$ patients. Subsequent evaluations of the results were independently performed by two observers (Y.K. and F.K.) in a blinded fashion. In cases where significant discrepancies were found between the judgments of these observers, a discussion was held and a consensus was reached. A semiquantitative scale from 0 to $3^{+}$was used for BIGH antigen staining as follows: $3^{+}$, intensely positive in both the cytoplasm and membrane of the RCC cells; $2^{+}$, positive cytoplasmic but weak membrane staining; $1^{+}$, weakly positive but stronger than normal; 0 , negative staining or as weak as normal.

Statistics. A paired t-test and a Mann-Whitney U test were used to test for differences in the distribution between the groups. Correlations were examined using the Spearman's rank correlation coefficient. Cause-specific survival rates of patients were determined by the Kaplan-Meier method and the differences were assessed using the log-rank test. All statistical analyses were performed using Stat View 5.0 software (Abacus Concepts, Berkeley, CA, USA). Statistical significance was taken at a $\mathrm{P}$-value of $<0.05$.

\section{Results}

Comparisons between the mRNA expression levels of BIGH3 and TGF- $\beta 1$ pathway-related genes in $c c-R C C$ and adjacent normal kidney tissue samples. The mRNA expression levels of $B I G H 3$ and of the $T G F-\beta 1$ related genes in cc-RCC (T) were compared with those in adjacent normal kidney tissue samples (N) by QRT-PCR of 30 normal kidney tissues and 53 cc-RCCs using a Taq Man PCR detection system. The mean \pm SD of the mRNA levels of each target gene (BIGH3, PAI- 1 and $T G F-\beta I)$ was normalized to that of $A C T B$ (Fig. 1A). The mRNA levels of the additional genes analysed in the $\mathrm{T}$ and $\mathrm{N}$ sample groups were $5.22 \pm 3.22$ and $5.36 \pm 2.16$ for $T G F-\beta R I I, 2.27 \pm 1.27$ and $1.73 \pm 0.49$ for $S M A D 4,3.92 \pm 2.33$ and $2.48 \pm 1.13$ for $S M A D 7$, respectively.

The mRNA levels of BIGH3, TGF- $\beta 1, P A I-1$ and SMAD7 were found to be significantly higher in the cc-RCC specimens compared with normal kidney samples $(\mathrm{p}<0.0001$ for $B I G H 3$, $T G F-\beta 1$ and PAI-1, $\mathrm{p}=0.0042$ for SMAD7). The mean fold changes in the T/average $\mathrm{N}$ values for $T G F-\beta 1, P A I-1$ and $S M A D 7$ were $4.4,4.5$ and 1.6 , respectively. The mean fold change of the T/average $\mathrm{N}$ of $B I G H 3$ was 27.0 . The $B I G H 3$ expression levels changed $>2$-fold in $49 / 53(92.5 \%$ ) specimens and $\geq 10$-fold in $28 / 53$ of these samples $(52.8 \%)$. The expression of TGF- $\beta R I I$ and SMAD4 was found to be comparable between tumors and normal kidney tissues.

The association between the expression of BIGH3 and TGF- $\beta 1$ pathway-related genes and the clinicopathological parameters obtained for the cc-RCC patients. We compared the mRNA expression levels of $B I G H 3$ and the $T G F-\beta 1$ related genes in our cc-RCC sample cohort with some of the clinicopathological data obtained for these corresponding patients (Table II). The average gene expression levels in the 30 normal kidney tissue samples were assigned a value of 1 , and the individual gene expression levels in the $53 \mathrm{cc}-\mathrm{RCC}$ samples was calculated relative to the normal average as $\mathrm{T} /$ average $\mathrm{N}$.

As shown in Table II, the expression of $T G F-\beta 1$ showed no correlation with any of the clinicopathological parameters. In sharp contrast, however, the down-regulation of $T G F-\beta R I I$ showed a significant correlation with each of these parameters. 
A
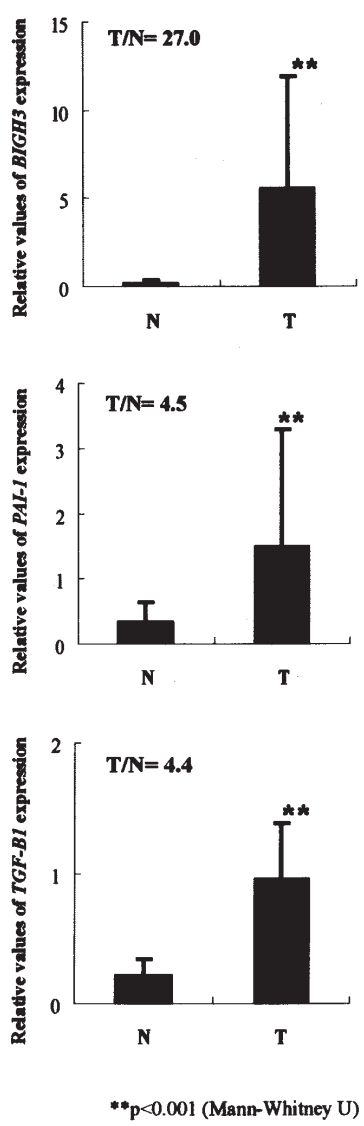

B
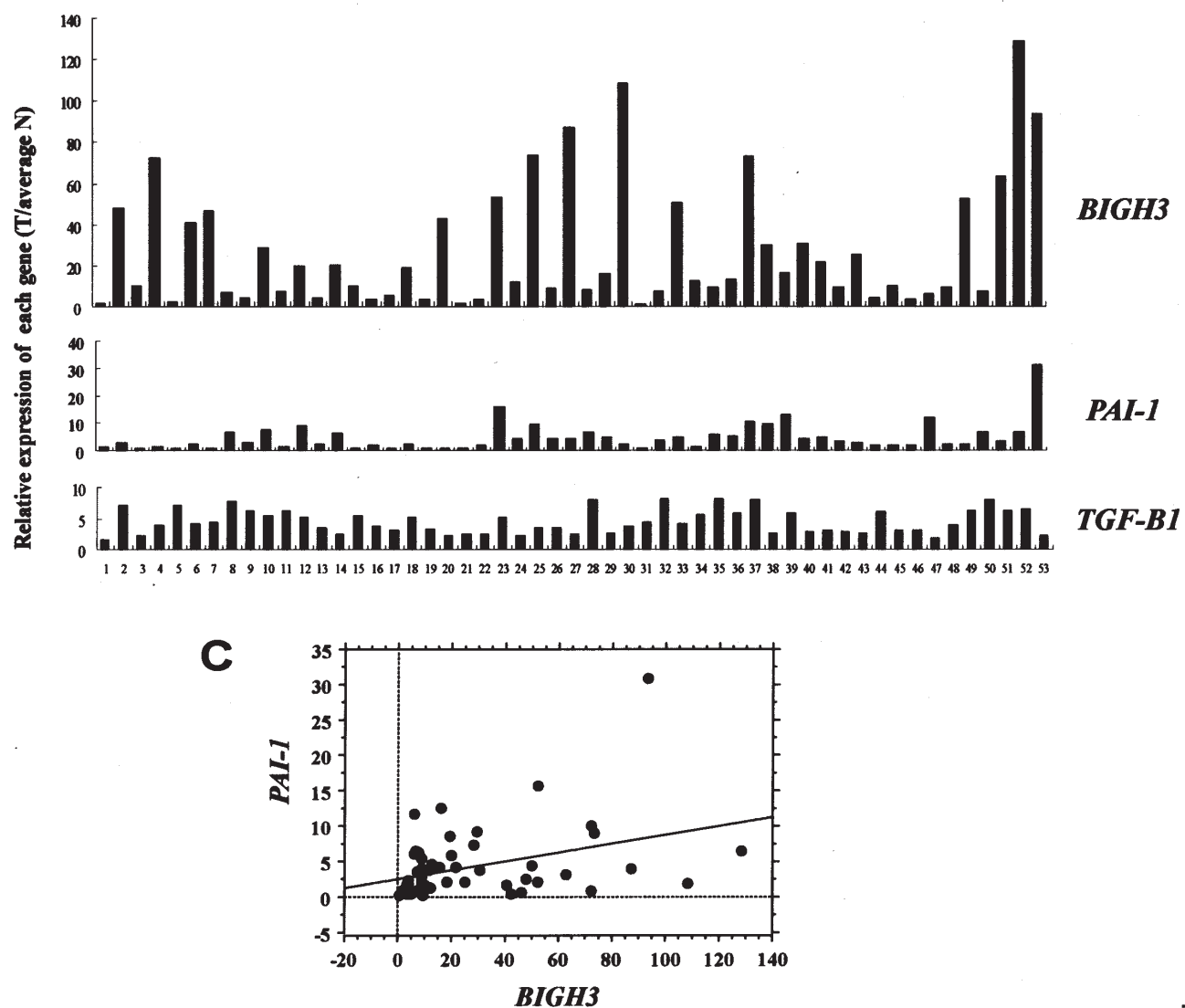

Figure 1. Comparison of the gene expression levels of BIGH3, PAI-1 and TGF- $\beta 1$ between cc-RCC (T) and adjacent normal kidney tissue samples (N), and their relationship to cc-RCC. (A) Determination of the expression levels of BIGH3, PAI-1 and TGF- $\beta 1$, normalized to ACTB, in 53 cc-RCCs (T) and 30 normal kidney tissue samples (N) by QRT-PCR. The mean fold changes in the T/average N values are indicated in each panel. (B) Relative mRNA expression levels of the indicated target genes for each of the cc-RCC samples in the current patient cohort $(\mathrm{n}=53)$ compared with the average values in adjacent normal kidney control specimens $(\mathrm{n}=30)$. (C) Positive correlation between $B I G H 3$ and PAI-1 expression (Spearman rank correlation coefficient $=0.443$, $\mathrm{n}=53$, $\mathrm{p}=0.0014)$.

The expression of PAI- 1 was found to be higher in the larger tumors $(>5 \mathrm{~cm}),(\mathrm{p}=0.0025)$, whereas that of SMAD4 was found to be reduced in both the larger and high-grade tumors (containing a G3 element), $(\mathrm{p}=0.0062$ and 0.0076 , respectively). The down-regulation of SMAD7 was also evident in patients with large tumors and high-stage tumors (stage III+IV), $(\mathrm{p}=0.012$ and 0.04 , respectively). Furthermore, the expression of BIGH3 was found to be significantly increased in high-grade tumors $(\mathrm{p}=0.0179)$.

We further examined the correlation between the selected genes (BIGH3, PAI-1 and TGF- $\beta 1)$ in individual cc-RCC samples $(\mathrm{n}=53)$ (Fig. 1B). Although the expression levels of $B I G H 3$ and $P A I-1$ varied widely, a significant correlation between $B I G H 3$ and PAI- 1 expression was evident (Spearman rank correlation coefficient $=0.443, \mathrm{p}=0.0014$, Fig. 1C). The $T G F-\beta 1$ expression levels remained relatively constant regardless of the cancer stage, and no significant correlation was observed between $B I G H 3$ and $T G F-\beta 1$ expression (Spearman rank correlation coefficient $=0.039, \mathrm{p}=0.7817$, data not shown). There was also a significant correlation found between the expression of TGF- $\beta R I I$ and SMAD4 (Spearman rank correlation coefficient $=0.721, \mathrm{p}<0.0001$, data not shown).
Analysis of BIGH3 expression by immunohistochemistry. We further examined the expression and cellular distribution of BIGH3 in 52 cc-RCC paraffin-embedded tissue samples by immunohistochemistry (IHC) using a polyclonal anti-BIGH3 antibody. Thirty-nine of these cases differed from those used in our earlier mRNA analysis and 13 cases overlapped between the two experiments. The mean follow-up period for the patients in this cohort was 50.9 months (range 1-125 months). The IHC staining intensities were scored as described in the Materials and methods section.

Positive cytoplasmic staining of BIGH3 was observed in the tumor cells in the majority of the RCC samples (Fig. 2B and area denoted by ' $\mathrm{T}$ ' in Fig. 2D). In contrast, only weak staining was evident in normal kidney tissue samples (region denoted by ' $\mathrm{N}$ ' in Fig. 2D). Strong BIGH3 staining was noted in the cytoplasm and also at the membrane in some RCC cases (Fig. 2A), and negative or weaker staining was observed in other samples (Fig. 2C). Weak staining was also observed in the proximal tubular cells, which are thought to be the origin of cc-RCC and negative staining was detected in the glomerulus (Fig. 2D). Non-specific staining was observed in the distal tubules and collecting ducts. The results of these analyses were consistent with the mRNA expression data as 45 


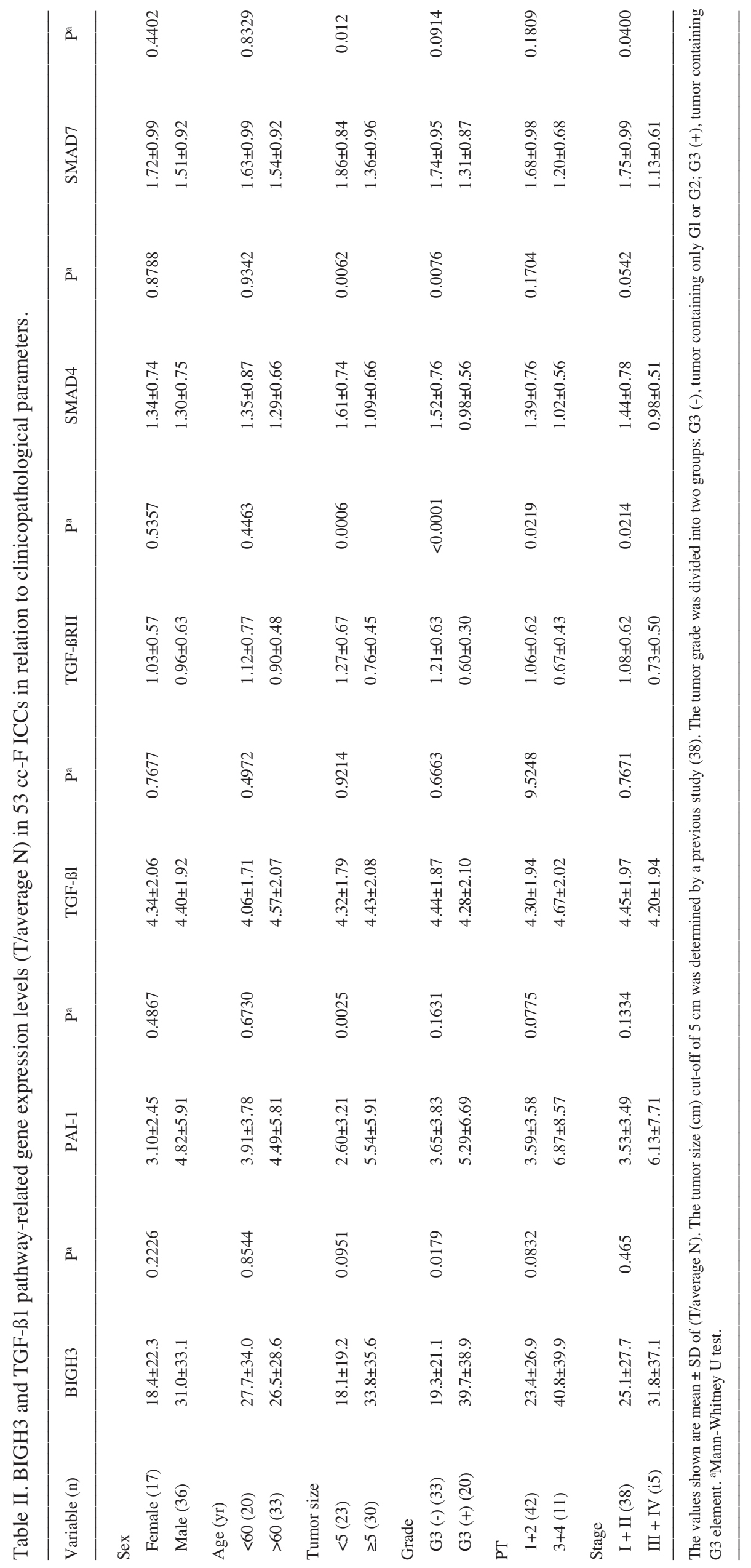



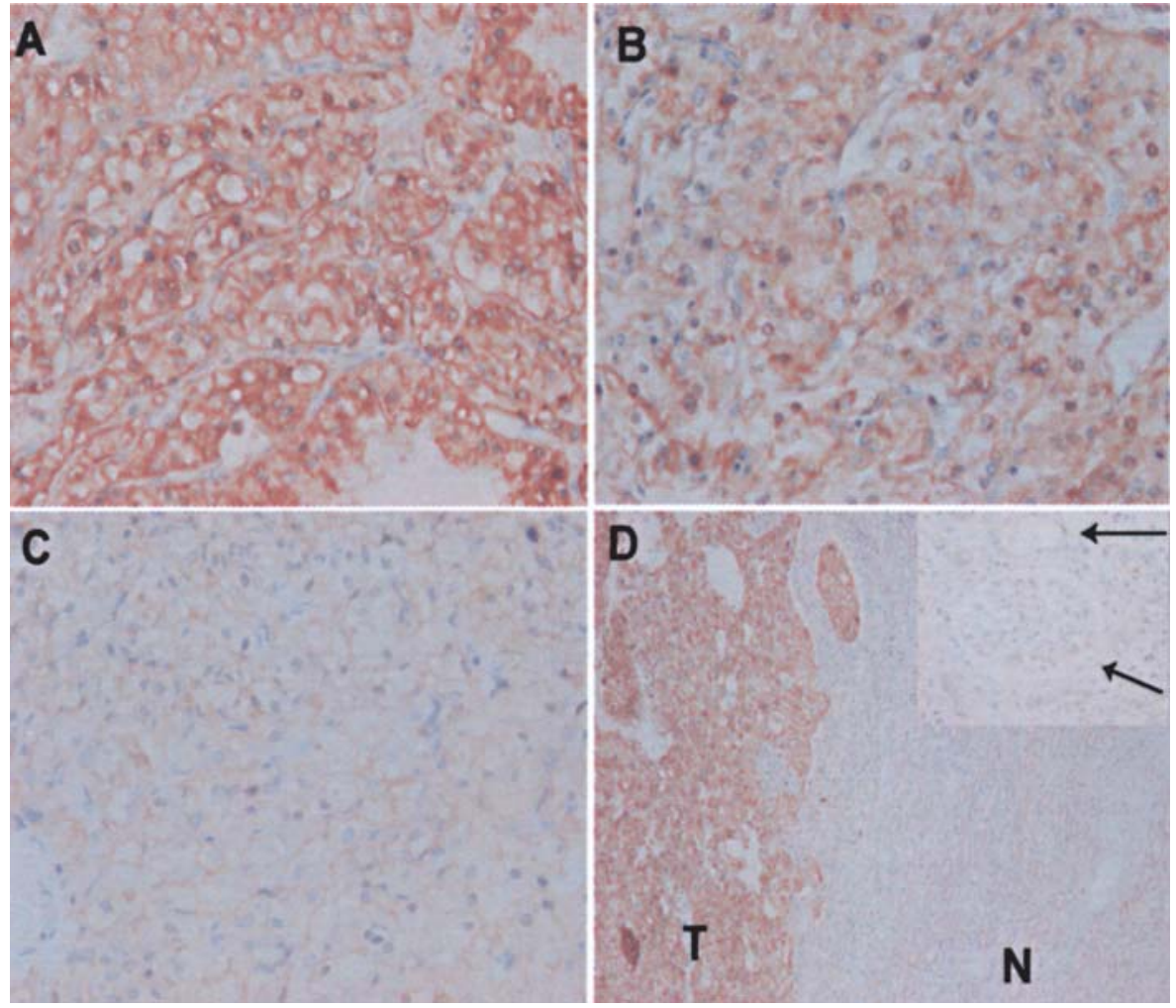

Figure 2. Immunohistochemical analysis of BIGH3 expression in paraffin-embedded RCC and kidney tissue samples. Tissue sections were immunostained using a polyclonal antibody raised against BIGH3 and counterstained with hematoxylin. (A) Representative RCC tissue section with a score of $3^{+}$. Strong $\mathrm{BIGH}$ staining is evident in the cytoplasm and membrane of the tumor cells. (B) Representative RCC tissue section with a score of $2^{+}$. Staining of BIGH3 is observed in the cytoplasm only. (C) Representative RCC tissue section that is BIGH3-negative (score 0), in which negative or weaker staining than normal can be observed. (D) Representative tissue section containing both RCC (T) and normal kidney cells (N). This specimen shows a marginal area of RCC, a pseudocapsule and a normal kidney area. Only the region containing RCC is intensely stained. The inset shows a higher magnification of the normal area; arrows indicate a glomerulus (below) and tubules (above). Original magnifications: A, B, C, and inset in D x200; D x100.

$(86.5 \%)$ cases were positive (score $1-3)$ and $34(65.4 \%)$ cases were strongly positive (score 2-3) for BIGH3.

To then investigate the association between tumor BIGH3 protein levels and patient survival outcomes, we divided the 52 RCC patients into two groups depending on the intensity of their BIGH3 immunostaining. Tumors with staining levels of $\leq 1^{+}$(18/52 tumors, $\left.34.6 \%\right)$ were considered to be low for BIGH3 and staining intensities $>2$ (34/52 tumors, $65.4 \%)$ were considered to be high for BIGH3. No significant association was found between the BIGH3 levels and cause-specificsurvival (log-rank test $\mathrm{p}=0.101)$, however, there was a tendency for high BIGH3 staining intensity to be associated with poor survival (estimated 5-year survival rate: $83.3 \%$ for low BIGH3 and $55.9 \%$ for high BIGH3).

Messenger RNA expression levels of TGF- $\beta 1, T G F-\beta R I I$, SMAD4, SMAD7, PAI-1 and BIGH3 in untreated RCC cells. We investigated $B I G H 3$ mRNA expression and the relationship with $T G F-\beta 1$ related genes including $T G F-\beta 1$, TGF- $\beta R I I, S M A D 4$, SMAD7 and PAI-1 in RCC cell lines and a 'normal' reference cell type, RPTEC $(\mathrm{n}=5)$. The basal levels of $B I G H 3$ were measured at $2.35 \pm 0.51,0.64 \pm 0.14,0.59 \pm 0.30$, $0.37 \pm 0.04$ and $0.33 \pm 0.07$ in SKRC44, SKRC49, ACHN, A498 and RPTEC, respectively. For PAI-1, these values were $0.58 \pm 0.26,0.02 \pm 0.006,0.02 \pm 0.006,0.09 \pm 0.04$ and
$0.80 \pm 0.55$, respectively and for $T G F \beta R I I$ were calculated to be $0.47 \pm 0.33,0.79 \pm 0.48,1.15 \pm 0.25,0.57 \pm 0.14$ and $3.12 \pm 1.79$, respectively. We found no appreciable differences in the basal levels of $T G F-\beta 1, S M A D 4$ and SMAD7 (data not shown). $B I G H 3$ expression was detectable in all of the cell lines tested, although these expression levels were not increased in the majority of the RCC cells compared with RPTEC, except for SKRC44. PAI-1 was also detectable in each cell line, although at much lower levels in the SKRC49, ACHN and A498 cells. The basal levels of BIGH3 expression were found not to correlate with those of $T G F-\beta 1$ or PAI- 1 (Spearman rank correlation coefficient $=0.268$ and $0.029, \mathrm{p}=0.189$ and 0.8861 , for $T G F \beta 1$ and $P A I-1$, respectively).

Relative expression changes of BIGH3 and PAI-1 after TGF- $\beta 1$ treatment. The induction of BIGH3 by TGF- $\beta 1$ was detectable in SKRC44, A498 and RPTEC cells, whereas much lower effects following this treatment were apparent in SKRC49 and ACHN cells. In a similar manner to BIGH3, $P A I-1$ was found to be significantly induced by TGF- $\beta 1$ in SKRC44, A498 and RPTEC cells, but either poorly or not induced at all in SKRC49 and ACHN cells (Fig. 3A). The profile of BIGH3 induction by TGF- $\beta 1$ thus resembles that of PAI-1, suggesting that they are regulated by a similar mechanism in RCC cell lines. 
A
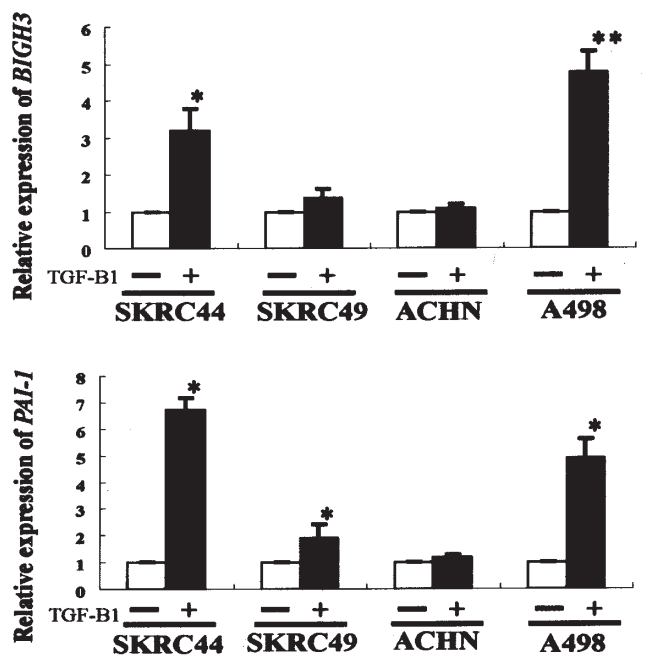
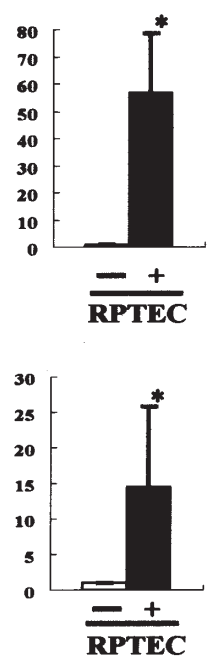

B

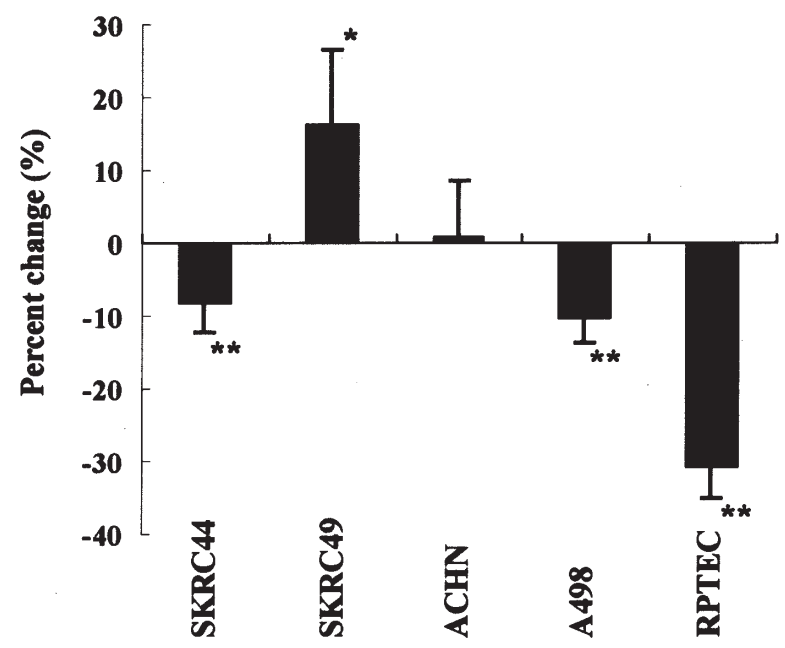

$* \mathrm{p}<0.05, * \mathrm{p}<0.0001$ (paired T-test)

Figure 3. Relative gene expression changes in $B I G H 3$ and $P A I-1$ after $T G F-\beta 1$ treatment and their effects on proliferation in RCC cell lines. (A) Measurement of BIGH3 and PAI-1 gene expression changes following TGF-B1 $(10 \mathrm{ng} / \mathrm{ml})$ stimulation, relative to untreated cells, by QRT-PCR. The expression level values were normalized to ACTB. The data shown (each cell line: $\mathrm{n}=5$ ) represent the mean $\pm \mathrm{SD}$. The BIGH3 expression levels are significantly increased in the SKRC44, A498 and RPTEC cell types following TGF- $\beta 1$ treatment (paired t-test, $\mathrm{p}=0.0021, \mathrm{p}<0.0001$ and $\mathrm{p}=0.0066$, respectively). PAI-1 expression is significantly increased in the SKRC44, SKRC49, A498 and RPTEC cells following TGFß1 treatment (paired t-test, $\mathrm{p}=0.0069$, $\mathrm{p}=0.0320$, $\mathrm{p}=0.0016$ and $\mathrm{p}=0.0045$, respectively). (B) Measurement of cell proliferation in the indicated RCC cell lines and normal kidney cells using the MTT assay after stimulation by TGF- $11(10 \mathrm{ng} / \mathrm{ml})$. The data represent the mean \pm SD of triplicate observations $(\mathrm{n}=12)$. The growth of the SKRC44, A498 and RPTEC cells was found to be inhibited by TGF- $\beta 1$, whereas SKRC49 cell proliferation was stimulated and ACHN cells showed no change following this exposure. (Paired t-test, $\mathrm{p}=0.0001$ for SKRC49, $\mathrm{p}<0.0001$ for SKRC44, A498 and RPTEC and $\mathrm{p}=0.6519$ for ACHN, compared with untreated cell controls in each case).

Effects of TGF- $\beta 1$ on cell proliferation in RCC cell lines. The proliferative properties of the four RCC cell lines under study and the RPTEC control following treatment with TGF- 31 were assessed using an MTT assay $(n=12)$. The proliferation of the SKRC44, A498 and RPTEC cell types was found to be inhibited by TGF- 1 , whereas SKRC49 cells exhibited a slight stimulation and the ACHN cells showed no change under these conditions (Fig. 3B).

\section{Discussion}

Our present study represents the first evaluation of the mRNA and protein expression profile of the BIGH3 gene in both RCC tissues and cell lines. The changes in the expression of this gene form part of the fundamental alterations in the activity of TGF- $\beta 1$ during the onset of RCC, as revealed by general changes in other genes investigated herein and in previous reports.

TGF- $\beta 1$ has been reported to be elevated in several cancer types including RCC $(5,23)$. In our current study, the $T G F-\beta 1$ mRNA levels were found to be significantly elevated in RCCs compared with normal tissues. It was previously reported that the plasma levels of TGF- $\beta 1$ are markedly up-regulated in patients with advanced (metastatic) RCC compared with localized tumors, suggesting an important role for this gene in RCC progression (5). It is noteworthy, however, that no correlation could be found between the $T G F-\beta 1 \mathrm{mRNA}$ levels and RCC progression in our present experiments.

A correlation between the loss or down-regulation of TGF-BRII expression and tumor progression has also been reported in a number of cancer types, including RCC (6). Decreased TGF-ßRII function has also been implicated in the escape of cancer cells from the growth inhibitory effects of TGF- $\beta(4,7)$. This is consistent with our current finding that $T G F-\beta 1$ is somewhat increased, whereas $T G F-\beta R I I$ expression is significantly decreased, with tumor progression.

Although no significant differences in the expression of SMAD4 between normal renal tissue and RCC were detectable in our present analyses, we did identify a correlation between the down-regulation of SMAD4 and a number of progression parameters for RCC. A concomitant down-regulation of $S M A D 4$ with tumor progression has also been observed in pancreatic and colon cancers $(24,25)$, though it has not been reported previously in $\mathrm{RCC}$. There was a significant correlation found between the expression of $T G F-\beta R I I$ and $S M A D 4$. Hence, in addition to the decrease in TGF- $\beta R I I$, the down-regulation of SMAD4 may be responsible, at least in part, for RCC progression.

SMAD7 is thought to exert inhibitory effects upon TGF-ß signalling, and to have a negative feedback function that regulates the intensity or duration of the TGF- $\beta 1$ response. In our current study, SMAD7 expression was observed to be up-regulated in RCC, but to be down-regulated with the onset of tumor progression. These observations may be explicable, however, if the $S M A D 7$ levels are considered to be the result of a negative feedback of active TGF- $\beta 1$ signalling, as postulated previously (26).

PAI-1 is an inhibitor of the plasminogen activating system that plays a key role in the tumor-associated proteolysis cascade. This cascade eventually leads to extracellular matrix 
degradation and stromal invasion. Hence, PAI-1 was previously thought to inhibit tumor invasion and metastasis, and thus be associated with a better prognosis. However, using IHC analyses, several investigators have reported that the expression of PAI-1 in cancer cells is higher than in normal cells, and that its levels could be inversely correlated with the survival rate in patients with a variety of carcinomas, including RCC (27-29). At the mRNA level, PAI-1 has been previously shown to be significantly elevated in RCC, though not to correlate with cancer grade or TNM classification (30). In this study, PAI-1 was found to be elevated in RCC and the overexpression of this gene was seen to positively correlate with certain progression parameters.

BIGH3 was originally isolated from the A549 lung adenocarcinoma cell line following exogenous TGF- 31 exposure and was thus recognized as one of its downstream target genes (9). There are conflicting reports, however, regarding its function in tumorigenesis. A possible tumor suppressor role has been previously suggested $(10,13,31)$, but the overexpression of $B I G H 3$ has been reported in several cancer tissue samples including RCC (14-16).

BIGH3 mRNA expression in RCC tissues was observed to be higher compared with normal kidney tissues in our present experiments. In addition, by IHC we found strong staining of BIGH3 in the majority (86.5\%) of the RCC tissues compared with their adjacent normal controls. Both the mRNA and protein analyses thus demonstrated increased BIGH3 expression in the majority of the RCC samples. A correlation between the BIGH3 and PAI- 1 mRNA levels was also evident, despite the negative correlation between $B I G H 3$ and $T G F-\beta 1$. These data therefore suggest that $B I G H 3$ is regulated in a similar manner to PAI-1 in RCC tissue samples.

We further investigated the relationship between $\mathrm{BIGH} 3$ and $T G F-\beta 1$ related genes in the RCC cell lines and in normal kidney cells (RPTEC). In the RPTEC cells, the BIGH3 and $P A I-1$ expression levels were dramatically induced by TGF- $\beta 1$ treatment. In a previous study of a diabetic nephropathy model, TGF- 31 was found to induce BIGH3 mRNA in a dose-dependent manner, and a significant correlation between BIGH3 and TGF- 31 was evident, from which it was concluded that BIGH3 would be a useful marker of TGF- $\$ 1$ bioactivity in the normal kidney (32).

The up-regulation of $B I G H 3$ and $P A I-1$ by TGF- $\beta 1$ stimulation was observed in SKRC44 and A498, but not in SKRC49 or ACHN cells. These data indicate that the transcriptional induction of both $B I G H 3$ and $P A I-1$ by TGF- $\beta 1$ is regulated via a similar mechanism in $\mathrm{RCC}$. In addition, the relationship between BIGH3 expression following TGF- 31 stimulation and the resulting proliferation of RCC cells shows that TGF- 11 slightly inhibits cell growth in the SKRC44 and A498 cell lines, but that the SKRC49 and ACHN cells are resistant to these inhibitory effects of TGFß1. Furthermore, BIGH3 was dramatically induced in RPTEC cells, which are highly sensitive to TGF- $\beta 1$ treatment. From these data, we thus hypothesise that increases in BIGH3 and PAI-1 expression following TGF- $\beta 1$ stimulation indicate the anti-proliferative effects and a positive signalling response in vitro. Since the activation of PAI-1 expression has been used as a marker for TGF- $\beta$-induced transcription in vitro (33), we speculated that the TGF- 31 -induced increases in the transcription of BIGH3 may likewise indicate a positive TGF- 31 signalling response in RCC cell lines as has been previously suggested (9).

It is noteworthy, however, that conflicting results concerning the role of $\mathrm{BIGH} 3$ were also obtained in our current study. Our cell line experiments suggest that the induction of BIGH3 and PAI-1 indicates an active response of these genes to TGF- $\$ 1$. However, our analyses of cancer tissue samples from RCC patients show that the increased BIGH3 expression can be correlated with parameters that indicate a poorer prognosis and a failing response to TGF- $\$ 1$. Hence, additional mechanisms that are independent of TGF- $\beta 1$ may influence the activity of BIGH3, and the relationship between TGF- 31 and BIGH3 seems to be more complex in vivo. It is therefore likely that $\mathrm{BIGH} 3$ has both positive and negative influences on RCC progression, in a similar manner to TGF- 11 and PAI-1.

Although our principal findings and conclusions regarding the function of BIGH3 in RCC cells were made using the TGF- $\beta 1$ stimulation model, we also constructed and introduced BIGH3 small hairpin RNAs (BIGH shRNA) into the BIGH3 overexpressing RCC cell line SKRC44 to further clarify the function of BIGH3 itself. This BIGH3 shRNA species produced $\sim 70 \%$ reduction in the BIGH3 mRNA levels compared with a GFP shRNA control, though did not have any apparent effects upon proliferation (data not shown). Further investigations will therefore be needed to elucidate the function of BIGH3 in RCC cells, but our shRNA analysis does suggest that BIGH3 itself cannot influence RCC proliferation.

$B I G H 3$ was characterized as a gene inducible by hypoxia and VHL alteration (34). In this study, $B I G H 3$ was reported to be dramatically overexpressed in 786-O cells lacking VHL. $V H L$ inactivation occurs in the majority of sporadic cc-RCC and has a crucial role in cc-RCC carcinogenesis (35). Hypoxia inducible factors (HIFs) are transcription factors that regulate the production of a number of downstream genes in response to hypoxia. In cc-RCC, due to VHL gene inactivation, HIF1 $\alpha$ is stabilized and accumulates, leading to the induction of its down-stream gene products $(36,37)$. Since $\mathrm{BIGH} 3$ is reported to be overexpressed following $V H L$ gene inactivation, this gene may be a critical component of cc$\mathrm{RCC}$ in the VHL/HIF pathway.

In summary, we found that BIGH3 is highly expressed in cc-RCC compared with normal kidney tissues and that this is predictive of a poorer prognosis, similar to PAI-1. Our data thus suggest that $\mathrm{BIGH} 3$ plays a role in cc-RCC and is a candidate biomarker of cc-RCC progression.

\section{Acknowledgements}

We are most grateful to Professor Wolfgang A. Schulz (Heinrich-Heine University, Germany) for his critical discussions and advice. We also thank M. Arai and T. Asano for their technical advice and S. Ohkura and A. Hada for their assistance with the preparation of this manuscript.

\section{References}

1. Motzer RJ, Bander NH and Nanus DM: Renal-cell carcinoma. N Engl J Med 335: 865-875, 1996. 
2. Tsui KH, Shvarts O, Smith RB, Figlin RA, deKernion JB and Belldegrun A: Prognostic indicators for renal cell carcinoma: a multivariate analysis of 643 patients using the revised 1997 TNM staging criteria. J Urol 163: 1090-1095, 2000.

3. Ljungberg B, Alamdari FI, Rasmuson T and Roos G: Follow-up guidelines for nonmetastic renal cell carcinoma based on the occurrence of metastases after radical nephrectomy. BJU Int 84: 405-411, 1999.

4. Derynck R, Akhurst RJ and Balmain A: TGF-beta signaling in tumor suppression and cancer progression. Nat Genet 29: 117-129, 2001.

5. Hegele A, Varga Z, von Knobloch R, Heidenreich A, Kropf J and Hofmann R: TGF-betal in patients with renal cell carcinoma. Urol Res 30: 126-129, 2002.

6. Miyajima A, Asano T, Seta K, Kakoi N and Hayakawa M: Loss of expression of transforming growth factor-beta receptor as a prognostic factor in patients with renal cell carcinoma. Urology 61: 1072-1077, 2003.

7. Copland JA, Luxon BA, Ajani L, Maity T, Campagnaro E, Guo H, LeGrand SN, Tamboli P and Wood CG: Genomic profiling identifies alterations in TGFbeta signaling through loss of TGFbeta receptor expression in human renal cell carcinogenesis and progression. Oncogene 22: 8053-8062, 2003.

8. Moustakas A, Souchelnytskyi S and Heldin CH: Smad regulation in TGF-beta signal transduction. J Cell Sci 114: 4359-4369, 2001.

9. Skonier J, Neubauer M, Madisen L, Bennett K, Plowman GD and Purchio AF: cDNA cloning and sequence analysis of beta ig-h3, a novel gene induced in a human adenocarcinoma cell line after treatment with transforming growth factor-beta. DNA Cell Biol 11: 511-522, 1992

10. Skonier J, Bennett K, Rothwell V, Kosowski S, Plowman G, Wallace P, Edelhoff S, Disteche C, Neubauer M, Marquardt H, Rodgers $\mathrm{H}$ and Purchio AF: beta ig-h3: a transforming growth factor-beta-responsive gene encoding a secreted protein that inhibits cell attachment in vitro and suppresses the growth of CHO cells in nude mice. DNA Cell Biol 13: 571-584, 1994.

11. Munier FL, Korvatska E, Djemai A, Le Paslier D, Zografos L, Pescia G and Schorderet DF: Kerato-epithelin mutations in four 5q31-linked corneal dystrophies. Nat Genet 15: 247-251, 1997.

12. LeBaron RG, Bezverkov KI, Zimber MP, Pavelec R, Skonier J and Purchio AF: Beta IG-H3, a novel secretory protein inducible by transforming growth factor-beta, is present in normal skin and promotes the adhesion and spreading of dermal fibroblasts in vitro. J Invest Dermatol 104: 844-849, 1995.

13. Zhao YL, Piao CQ and Hei TK: Downregulation of Betaig-h3 gene is causally linked to tumorigenic phenotype in asbestos treated immortalized human bronchial epithelial cells. Oncogene 21: 7471-7477, 2002

14. Boer JM, Huber WK, Sultmann H, Wilmer F, von Heydebreck A, Haas S, Korn B, Gunawan B, Vente A, Fuzesi L, Vingron M and Poustka A: Identification and classification of differentially expressed genes in renal cell carcinoma by expression profiling on a global human 31,500-element cDNA array. Genome Res 11: 1861-1870, 2001

15. Liou LS, Shi T, Duan ZH, Sadhukhan P, Der SD, Novick AA, Hissong J, Skacel M, Almasan A and DiDonato JA: Microarray gene expression profiling and analysis in renal cell carcinoma. BMC Urol 4: 9, 2004.

16. Yao M, Tabuchi H, Nagashima Y, Baba M, Nakaigawa N, Ishiguro H, Hamada K, Inayama Y, Kishida T, Hattori K, Yamada-Okabe $\mathrm{H}$ and Kubota Y: Gene expression analysis of renal carcinoma: adipose differentiation-related protein as a potential diagnostic and prognostic biomarker for clear-cell renal carcinoma. J Pathol 205: 377-387, 2005.

17. Sasaki H, Kobayashi Y, Nakashima Y, Moriyama S, Yukiue H, Kaji M, Kiriyama M, Fukai I, Yamakawa Y and Fujii Y: Beta IGH3, a TGF-beta inducible gene, is overexpressed in lung cancer. Jpn J Clin Oncol 32: 85-89, 2002.

18. Hourihan RN, O'Sullivan GC and Morgan JG: Transcriptional gene expression profiles of oesophageal adenocarcinoma and normal oesophageal tissues. Anticancer Res 23: 161-165, 2003.

19. Schneider D, Kleeff J, Berberat PO, Zhu Z, Korc M, Friess H and Buchler MW: Induction and expression of betaig-h3 in pancreatic cancer cells. Biochim Biophys Acta 1588: 1-6, 2002.
20. Buckhaults P, Rago C, St Croix B, Romans KE, Saha S, Zhang L, Vogelstein B and Kinzler KW: Secreted and cell surface genes expressed in benign and malignant colorectal tumors. Cancer Res 61: 6996-7001, 2001

21. Guinan P, Sobin LH, Algaba F, Badellino F, Kameyama S, MacLennan G and Novick A: TNM staging of renal cell carcinoma: Workgroup No. 3. Union International Contre le Cancer (UICC) and the American Joint Committee on Cancer (AJCC). Cancer 80: 992-993, 1997.

22. Japanease Urological Association: General Rule for Clinical and Pathological Studies on Renal Cell Carcinoma, 3rd Edition. Kanehara Company, Tokyo, 1999.

23. Wunderlich H, Steiner T, Junker U, Knofel B, Schlichter A and Schubert J: Serum transforming growth factor-beta1 in patients with renal cell carcinoma. J Urol 157: 1602-1603, 1997.

24. Luttges J, Galehdari H, Brocker V, Schwarte-Waldhoff I, Henne-Bruns D, Kloppel G, Schmiegel W and Hahn SA: Allelic loss is often the first hit in the biallelic inactivation of the p53 and DPC4 genes during pancreatic carcinogenesis. Am J Pathol 158: $1677-1683,2001$.

25. Alazzouzi H, Alhopuro P, Salovaara R, Sammalkorpi H, Jarvinen H, Mecklin JP, Hemminki A, Schwartz S Jr., Aaltonen LA and Arango D: SMAD4 as a prognostic marker in colorectal cancer. Clin Cancer Res 11: 2606-2611, 2005.

26. Osawa $H$, Nakajima $M$, Kato $H$, Fukuchi $M$ and Kuwano $H$ : Prognostic value of the expression of Smad6 and Smad7, as inhibitory Smads of the TGF-beta superfamily, in esophageal squamous cell carcinoma. Anticancer Res 24: 3703-3709, 2004.

27. Robert C, Bolon I, Gazzeri S, Veyrenc S, Brambilla C and Brambilla E: Expression of plasminogen activator inhibitors 1 and 2 in lung cancer and their role in tumor progression. Clin Cancer Res 5: 2094-2102, 1999.

28. Hazelbag S, Kenter GG, Gorter A and Fleuren GJ: Prognostic relevance of TGF-beta1 and PAI-1 in cervical cancer. Int J Cancer 112: 1020-1008, 2004.

29. Ohba K, Miyata Y, Kanda S, Koga S, Hayashi T and Kanetake H: Expression of urokinase-type plasminogen activator, urokinasetype plasminogen activator receptor and plasminogen activator inhibitors in patients with renal cell carcinoma: correlation with tumor associated macrophage and prognosis. J Urol 174: 461-465, 2005 .

30. Wagner SN, Atkinson MJ, Thanner S, Schmitt M, Wilhelm O, Rotter $\mathrm{M}$ and Hofler H: Type-1 plasminogen activator inhibitor in human renal cell carcinoma. J Pathol 179: 95-99, 1996.

31. Becker J, Erdlenbruch B, Noskova I, Schramm A, Aumailley M, Schorderet DF and Schweigerer L: Keratoepithelin suppresses the progression of experimental human neuroblastoma. Cancer Res 66: 5314-5321, 2006.

32. Gilbert RE, Wilkinson-Berka JL, Johnson DW, Cox A, Soulis T, Wu LL, Kelly DJ, Jerums G, Pollock CA and Cooper ME: Renal expression of transforming growth factor-beta inducible gene-h3 (beta ig-h3) in normal and diabetic rats. Kidney Int 54: 1052-1062, 1998.

33. Dong C, Zhu S, Wang T, Yoon W, Li Z, Alvarez RJ, Dijke PT, White B, Wigley FM and Goldschmidt-Clermont PJ: Deficient Smd7 expression: a putative molecular defect in scleroderma. Proc Natl Acad Sci USA 99: 3908-3913, 2002.

34. Jiang Y, Zhang W, Kondo K, Klco JM, St Martin TB, Dufault MR, Madden SL, Kaelin WG Jr and Nacht M: Gene expression profiling in a renal cell carcinoma cell line: dissecting VHL and hypoxia-dependent pathways. Mol Cancer Res 1: 453-462, 2003.

35. Kaelin WG Jr: The von Hippel-Lindau tumor suppressor gene and kidney cancer. Clin Cancer Res 10: 6290-6295, 2004.

36. Linehan WM: Molecular targeting of VHL gene pathway in clear cell kidney cancer. J Urol 170: 593-594, 2003.

37. Sufan RI, Jewett MA and Ohh M: The role of von Hippel-Lindau tumor suppressor protein and hypoxia in renal clear cell carcinoma. Am J Physiol Renal Physiol 287: F1-F6, 2004.

38. Elmore JM, Kadesky KT, Koeneman KS and Sagalowsky AI: Reassessment of the 1997 TNM classification system for renal cell carcinoma. Cancer 98: 2329-2334, 2003. 